\title{
The state in the era of India's sub-national regions: Liberalization and land in Gujarat
}

Nikita Sud, University of Oxford

\section{Abstract}

Sub-national regions are at the centre of the global, neo-liberal economy. In India, the broadening of democracy has shifted the onus from centralized, national parties, to regional and identity-based ones, with implications for governance. Further, sub-national states have become drivers of development, and compete within and outside national boundaries to attract investment. In the era of regions, the state is varyingly understood as undergoing 'rescaling', 'reinvention' and 'restructuring'. This entity is key to understanding the regionalisation of the new economy. Taking land as the infrastructural base of liberalising India, this paper explores the evolution of the ideas, policies and politics of the sub-national state in Gujarat, in the field of land. Gujarat is one of India's foremost liberalizers. Dominant classes that shaped partial land reform, and subsequent land liberalization, and a bureaucracy and political machinery that has worked closely with international, national and regional capital, are critical to Gujarat's land economy. These conditions have not been replicated across India. The era of the regions has deep roots in history, institutions and politics, and it is generating winners and losers. Meta-narratives of change in the nature of the state are attractive theoretically, but they need to be tested against empirical contexts.

Keywords: sub-national state, regional development, economic liberalization, land, Gujarat, India

\section{Introduction}

India really is a sub-continent, and a very diverse one at that. India's regions ${ }^{1}$ are large enough to be countries, but are rather understudied ${ }^{2}$. This is because in the first four decades after independence, Delhi was seen to call the political, financial, and developmental

\footnotetext{
1 'Region' connotes the federal units of the Indian union. The term suggests geographical scale, and formal political boundaries. Officially, India's 28 federal units are called States. However, in this paper, the word region is being used to avoid confusion with the (administrative) 'state', which specifically refers to the bureaucratic governmental apparatus, with its attendant norms and politics. Scholars who similarly use the word 'region' include Sinha (2005) and Kohli (2012).

${ }^{2}$ Notable exceptions include Schomer, Erdman and Lodrick (1994) on Rajasthan; Kulke and Schenepel (2001) on Orissa; Corbridge, Jewitt and Kumar (2004) on Jharkhand; Yagnik and Sheth (2005) on Gujarat; and Pai (2007) on Uttar Pradesh.
} 
shots. Here was a centralized system, with one national political party virtually monopolising power, and distributing largesse through beholden satraps in the regions (Kothari, 1964). In the age of development planning, regional states vied for the best deal from each five year plan, lobbying Delhi to locate a dam or steel factory in their territories (Sinha, 2004). The central state was expected to consider these demands based on lofty ideals such as unity in diversity, regional equality and developmental balance, and of course upcoming elections and the requirements of patronage (Frankel, 2005).

The political economy and geography of federalism, centred on the national state, is a thing of the past. Economic reforms and the emphasis on decentralized 'good governance' have put the onus of development and economic growth on the regions. Moreover, the broadening of India's democracy has introduced many regional parties into the political mix, as also ethnic identity-based parties that often originate from, and are dominant in, a region (e.g. the Samajwadi Party and Bahujan Samaj Party in Uttar Pradesh, and the Dravida Munnettra Kazhagam in Tamil Nadu). The attendant decline of the Congress has inaugurated an era of coalitions, with regional interests gaining a newfound, powerful voice in national politics. Bargaining for resources has ensued, buttressed by the real threat of the national government falling if regional players' demands are not met. In short, politics, economics and geography are all pointing region-ward in contemporary India.

New Delhi continues to make policy, for instance, regarding foreign direct investment, opening up the wholesale and retail sector to international players, or the encouragement of export-led growth through the policy tool of Special Economic Zones. However today, much more than in the past, the regions are able to build on, or refract, from these impulses, depending on locally contingent factors. This paper argues that the nuance that is derived by disaggregating development, economics and politics from the centre to the regions, must not be lost by aggregation at the regional level. It makes a case for the study of the unique contemporary development trajectories of India's regions, particularly by tracing the opening up of specific sectors and resources.

The paper is structured as follows: in the first section, I review some of the literature on regions and economic reform in India. Then, I discuss inter- and multi-disciplinary conceptualisations of the neo-liberal transition of the state, arguing that this actor offers valuable insights on the nature of, and variations in, regional development today. In the second section, I introduce a regional state apparatus, that of Gujarat, which has been economically dynamic in the period of reform. I also place this dynamism in the comparative setting of other Indian regions. Section Three pinpoints the systematic liberalization of land 
as the base on which Gujarat's economic vitality is built. To interrogate the smooth roll-out of land liberalization, Section Four explores the historical, institutional and political context of land policy. The state is at the centre of this analysis.

The paper concludes that land deregulation is an apt example of Gujarat's mix of market-friendly liberalization, onto which practices, both legal and extra-legal, that are friendly to specific businesses are layered on a case-by-case basis. This combination of market- and business-friendliness ${ }^{3}$, has not been attained by many Indian regions, as evidenced by constrictions being faced in land markets across India. The experience of land liberalization in Gujarat corroborates existing literature, and furthers our understanding of the unevenness of regional development. Moreover, by highlighting the deregulation of land as a policy, empirically, the paper adds value to the on-going debate on land in India, moving this away from the focus on land acquisition by the state.

\section{Regions, reform, and the state}

In the literature, the relationship of India's regions with economic reform is addressed via macro analysis, as well as geographically-specific studies. One of the better-known works comes from Jenkins (1999), who points to the importance of India's federal structure for the reform process. He indicates that potentially politically explosive reform has been carried through with a passing of the buck between the centre and regions. Processes of bargaining between the centre and regions, as also between regions is typical of the reform process. Sinha (2005) suggests that institutional continuity marks the reception and implementation of economic reforms in the regions. India's regions have had diverse developmental trajectories, even in the era of centralized economic planning. This points to differences in historical and economic contexts, which have subsequently been built upon in the open market era. Moreover, while competition between the regions played out 'vertically' through New Delhi in the past, today it has shifted to a 'horizontal' plane, with opportunities for economic development being contested at the sub-national level.

Vijayabaskar (2010) too makes the point about the relevance of historical trajectories. He emphasises structural changes in the economy, and evolution in the polity, that has made an economic frontrunner like Tamil Nadu more open to reform than other regions. In the sphere of land acquisition for SEZs in particular, protest has been quite absent in Tamil Nadu, which is in marked contrast to the experiences of West Bengal, Orissa or even Maharashtra.

\footnotetext{
${ }^{3}$ See Kohli $(2006,2012)$ for an elaboration of the concept of business-friendliness
} 
Among other factors, Vijayabaskar attributes this to the anti-caste movement that has for long encouraged the move away from rural agricultural economies towards the urban manufacturing and service sectors. In this situation, rural landowners have been willing to accept competitive prices being offered by the state and SEZ developers, in exchange for agricultural land.

Finally, drawing us to the conditions of the losers, rather than the winners of the reform process is Corbridge (2011), who indicates that the basic environment for economic reform remains absent in Bihar and Jharkhand. Their leadership may speak the language of reform, and it may interact with potential investors in exercises that market their region, however, integration with the world and Indian economy is at most at the level of 'accumulation by dispossession'. There is a history of resource extraction, in the form of mining, deforestation, and the supply of cheap labour. This has enriched local elites, much as in the case of the African 'resource curse' (Collier, 2007). The benefits of economic exploitation have not reached the majority of the populace, leaving economic infrastructure in shambles. Forget economic reform, or a change in the nature of the state in the context of economic reform; the state has been and continues to be absent in large parts of central and eastern India. It is thus not a coincidence that these areas are in the midst of a Maoist insurgency.

The literature advises against over-optimism about the renaissance of the regions. Regional spaces may indeed be experiencing a newfound prominence in India's contemporary politics and economy; however, this prominence is not universal or even new, it has deep roots in history, institutions and local politics; and it is throwing up winners as well as losers. Whether explicit or not, the state apparatus is a prominent, even central presence in discussions about reform in the regions. After Abrams (1988), I see this entity as a multi-layered device, comprising ideas, institutional practices, as well as politics. Thus, the state is a discursive direction-giver, enabler and legitimator; it generates policy, and is an institutional driver; and it is embedded in and/or in engagement with legislative, party, and social movement politics. These multiple levels of stateness ${ }^{4}$, of what the state can be and do, will be reflected in my analysis of Gujarat's land policies below. But before I explore Gujarat's state, it will be useful to see representations of this entity in the literature on liberalization and globalisation, from various disciplinary perspectives.

\footnotetext{
${ }^{4}$ Stateness has varied meanings. For Nettl (1968) it refers to the institutional centrality of the state in political life; for Tilly (1975) it is about the effectiveness of state functions such as the formulation and implementation of policy, the articulation and protection of rights, the establishment of political institutions and engagement with a diverse population. My usage of stateness is concerned with the capacity and vision of the state.
} 
Given the changing balance of the national and regional state in the contemporary economy and polity, studies have pointed to a process of state re-scaling in India (Kennedy, 2009). This term draws on the work of geographer Neil Brenner (2004), and is an important concept for contemporary times. State rescaling goes beyond the suggestion that globalisation is undercutting the state. Instead, it proposes that the state is being turned 'inside-out' and 'outside-in' (Brenner, 1999: 437, citing Soja, 1992). This means that IFIs and international organisations have a greater say in the affairs of national states, and the theatre of stateness is turning to more regional arenas. States are going 'glocal' in the words of Brenner, and are changing in specific ways. Like the world cities of Tokyo, London, and New York, glocal states and regions are tied into the world economy, bypassing or not quite connected to national state boundaries anymore. Circuits of capital function glocally through these rescaled states and the rescaled urban conglomerations that represent them. Delhi-Gurgaon-Noida and Mumbai-Pune represent glocal space in India.

'Rescaling' offers a fresh perspective on the state from the lens of political geography; other studies have considered this entity from analytical interfaces offered by political science, political economy and sociology. These perspectives, of course, can be on different parts of the policy and ideological spectrum. In the more economically liberal and state minimalist estimates, the state has shifted gears from occupying a central economic role, to now being a facilitator of the economy, albeit from the regulatory sidelines. This restructured and downsized 'state in a changing world' (World Bank, 1997) is expected to work with (rather than for, as in the past) the market and civil society to achieve development.

On the other hand, studies of state 're-structuring', 'reinvention', and 'embedded autonomy' imply an ongoing re-orientation of the state, rather than a sidelining. Jessop (1999), for instance, acknowledges the erosion of the Keynesian Welfare National State (KWNS). Yet, for him, the state remains the site for the key function of politics and social cohesion. It is also a space for struggle among competing economic forces, be they global, regional or local. State managers jealously guard this role even as they concede other functions. On the lines of a changing, but still developmentally active state, Evans (1995) has considered the concept of 'embedded autonomy', a specific enabling connection between the state and elite interests in society. This connection is visible in some emerging sectors like Information Technology (IT) in India, where relevant government departments have played promotional and facilitating roles, almost like 'midwives', from the 1980s. Sud (2012) has written about the 'reinvention' of the contemporary state in India, where this entity has 
emerged as a pro-business facilitator of capital in the economy, and an ally of ethnic majorities in the democratic polity.

The literature cited in this section, whether pertaining to sectors, or geographic scale, or developmental directions, focuses our attention on nuanced regional and regional-state entities, in engagement with an increasingly complex and dynamic economy. This trend in the literature is a refreshing change from the dominant perspective of studying India, and its centralized monolithic 'black box' state, as a whole. How can we translate India's complex regional state in the abstract, to an actual case? Further, to pose the central question of this paper: what is the role of the regional state in the dynamism of the new economy? I turn my attention to Gujarat.

\section{Gujarat as an arena of reform}

With the fall of the Washington Consensus (Gore, 2000), it is now more widely acknowledged that neo-liberalism is an economic construct, with varied ideational and institutional origins (Toye, 1987; Chang, 2004). As a result, policies of liberalization too vary vastly. In the Indian setting, reform can mean rather different things across the country in both time and space. Given this, I have chosen to highlight three arenas of reform where the regional state has been significant, and which are important to Indian regional economies: (a) economic and political incentives for private investment, (b) reduction in tax, and (c) the promotion of infrastructure provision through the private sector or public-private partnerships. After looking at each theme, I will pick one: infrastructure policy, and place this in a comparative setting with other regions. Finally, having sketched some basic contours of the state in a liberalizing arena, I will detail the state's liberalisation of land.

In the early years of liberalization, observers commented on a lack of policy direction in Gujarat. Instead, the political leadership tended to bargain with the national state for economic incentives for its chosen businesses. This bargaining was routinely couched in chauvinistic notions of Gujarati pride and self-respect (asmita). According to the then Union Petroleum Secretary for instance, the government of Chief Minister Chimanbhai Patel aggressively lobbied the centre to 'revise the oil royalty upwards and provide special dispensations to Gujarat for the setting up of a private-sector export-oriented refinery' (Godbole, 1996: 241). The project in question is that of Reliance Refineries Pvt. Ltd., with a capacity of 27 million tonnes per annum, and a cost of Rs. 5142 crores ( $\$ 915.6$ million). The state's business-friendliness is evident across political dispensations, right up to the present day BJP government. This led the political opposition to suggest in 2007 that contrary to the 
BJP's election rhetoric that it serves 'five crore Gujaratis' (50 million), it is actually exclusively in the service of 'five crorepatis' (multi-millionaires) (Trivedi, 2007). Despite these allegations, state policy has also attempted more widely market-friendly measures, as demonstrated below.

Gujarat's broad political consensus over liberal reforms is visible in measures for tax reduction. India's Constitution allows regional legislatures to levy taxes on the entry of consumer goods into a local area. Gujarat's legislature had empowered local councils to collect Octroi tax, typically between 3 and 8 per cent of the price of a good. Octroi generated revenue, but was also a source of corruption. Traders and manufacturers consistently demanded its removal. Their calls were addressed under the national change in economic direction, as regions were able to provide tax and cost-related incentives to the manufacturing sector. In 2001, the Janata Dal-led government of Gujarat scrapped Octroi in 480 councils. In 2007, the BJP government removed Octroi altogether, even from the seven biggest cities. Revenue loss from this action is estimated at Rupees 1800 crore (\$320.7 million) per annum. The government indicated that it would work with trade associations to come up with a replacement for Octroi, such as VAT (Raghu, 2007). This has not emerged yet.

Moving on to infrastructure development in order to encourage private entrepreneurship, this is a provision advocated by IFIs such as the World Bank (1994), and by the Indian government, particularly from the $11^{\text {th }}$ Plan Period (2007-12). Infrastructure in power, roads, railways, ports and telecommunications can be promoted through the public sector, or via public-private partnerships (PPPs). Within the federal structure, regional highways, ports, urban infrastructure, and intra-regional transmission and distribution, as well as the bulk of power generation, is with sub-national units (Government of India, 2010).

The Gujarat Infrastructure Development Board (GIDB) was established in 1995. The Chief Minister is its chairman. In 1999, the Gujarat Infrastructure Development (GID) Act provided a framework for the participation of private players in financing, constructing, maintaining and operating infrastructure projects. Gujarat Infrastructure Vision 2010 (launched in 1999), summarized the agenda for infrastructure development for the coming decade. It identified 383 projects with an investment potential of Rupees 116,000 crores that would be its focus (Government of Gujarat, 2005a).

To illustrate the content of infrastructure policy thinking and practice, I will briefly discuss reforms in the power sector. In 1991, the Government of India altered the Electricity Supply Act in order to allow private participation in the generation, transmission and distribution of power. In its Power Policy of 1995, Gujarat replicated this sentiment. It also 
sought to augment regional generation by encouraging the setting up of captive power capacity by industrial units. No techno-economic clearances were needed for projects up to Rupees 400 crores. The Gujarat Electricity Board (GEB) could purchase any surplus from captive units on mutually agreed terms (Government of Gujarat, 1998).

In 1995, several new power projects were underway, including Reliance at Sikka (500 Megawatts, MW), Essar at Hazira (515 MW) and Gujarat Mineral Development Corporation at Akrimota (250 MW). By 2002, almost a quarter of Gujarat's power was generated by captive plants. Power sector reforms have had a mixed impact on Gujarat's bottom line. Reduction in farm subsidies and more efficient production and distribution has reduced GEB's losses from Rupees 2,200 crores in 1999-2000 to Rupees 475 crores in 2002-03. On the other hand, new pressure points have been created in the system, mainly through the propping up of large private interests.

In 2005, GEB claimed that Essar Power Ltd (EPL) owed it Rupees 1850 crore. The matter was referred to the Gujarat Electricity Regulatory Commission. Part of the claim related to EPL's wrongful use of incentives and pending Sales Tax. The rest pertained to its division of its 515MW power plant into two units on paper, one with the status of an independent power producer (IPP) and the other with that of a captive power plant (CPP). Political compulsions had led GEB to enter into an agreement to buy power from the 300 MW IPP. Even when GEB was not using the power fully, it had to pay for it. This excess capacity was then being used by Essar Steel at lower CPP rates, rather than being purchased from GEB. This was a win-win for Essar but amounted to huge losses for the government, which was also being deprived of electricity duty worth tens of crores per year (Bhatt, 2005).

It can be argued that my first example of economic and political incentives is a business-friendly measure, whereas the second one of tax reform is more generally marketfriendly. The third illustration of infrastructure provision in the power sector exemplifies market-friendly reform, which is then fine-tuned to further benefit specific businesses. Comparatively speaking, one could suggest that liberal policies, such as the improvement of infrastructure through PPPs, have been attempted in many Indian regions. Table 1 illustrates this.

*Table 1 here*

Regional Infrastructure Development Acts are declarations of the formalisation of a reformist policy direction. Yet, as the Chief Minister of Rajasthan has admitted, progress for 
many regions has been slow. Often, the creation of a land bank, or the liberalization of land laws is needed, in order for this resource to be available for rapid infrastructure development on a PPP basis (Times News Network, 2011). Regions such as Uttarakhand too have a PPP cell, which declares its novice status in the following introductory message:

\begin{abstract}
PPP [...] has now become mainstay of government's infrastructure development plan world over. Uttarakhand being one of the newest states of our country, needs to develop its infrastructure faster in order to catch up with the other states and world as whole. Keeping this vision in mind Uttarakhand has become part of DEA [Department of Economic Affairs], GoI [Government of India] and ADB [Asian Development Bank] promoted Technical Assistance program "Mainstreaming of PPP in states". Uttarakhand PPP Cell has been established under this program as a Technical Secretariat for all PPP related issues of Government of Uttarakhand (sic).
\end{abstract}

- Uttarakhand PPP Cell, http://cell.upppc.org/

Uttarakhand, Rajasthan and others like them may well be implementing pro-reform measures. However, they are still reliant on agencies like the ADB and the Government of India, which are attempting to standardize reformist practices across regions. What we have so far is not a level playing field. Some regions are well ahead of most, having infrastructure acts in place as early as 1999 . There is also a vast gap in the amount of investment attracted through this route. Gujarat heads this ranking. The next section will argue that certain legal and extra-legal processes in the opening up of land have formed the base for Gujarat's pole position in reforming infrastructure and other markets. Both in making policy, and in being willing to extend itself beyond this, Gujarat's state is at the center of the new land economy.

The remaining paper is based on primary qualitative research. It is thus apt to present here a note on methodology. This paper is part of a larger project on the interaction of liberalization and Hindu nationalism, and the long-term role of the state in Gujarat (Author, 2012). Field research was conducted over 13 months in 2003-05, with a repeat visit in 2008. Semi-structured interviews have been carried out with politicians, bureaucrats, academics, NGO workers, farmer leaders and business executives. This data has been corroborated using secondary publications, as well as newspaper articles, grey literature produced by NGOs as also business and political associations, and government policy documents. The primary and secondary documentary sources have been monitored until the time of writing. Despite attempts at triangulation, the basically sensitive nature of research on the state and political economy at the interstices of legality, means that all data cannot be corroborated, and the project cannot aspire to be large scale and comparative. Yet, one can argue that scholarship on the Indian experience of liberalization needs this kind of detailed work on the ground. Too often, broad-brush comparisons fail to go beyond the formal and visible, and are thus not illuminating. Having said that, after the completion of the Gujarat research, I have recently 
embarked on an in-depth study of changing land markets in West Bengal and Tamil Nadu, and have also conducted research in New Delhi. Brief mention is made of primary material from the latter phase of my work in the following section. Detailed findings are forthcoming in other publications.

\section{Proactively liberalizing Gujarat's land}

To meet rapidly expanding economic opportunities, from 1987, Gujarat has had a slew of land liberalization initiatives. State policy has been to steadily deregulate land, irrespective of the party in power. Quite characteristically, this is well before the issue of land acquisition for the players of the new economy came into the national spotlight, with protests over West Bengal's Singur and Nandigram, and Orissa's Posco only hitting the national headlines from the mid-2000s. To elaborate, in 1987, the Government of Gujarat announced the withdrawal of Section 2(6) of the Bombay Tenancy and Agricultural Land Rules. This clause is popularly known as the '8-kilometre rule', and symbolized the stance of 'land to the tiller' that underlay post-independence land reform. The rule disallowed purchase or sale of agricultural land beyond an 8 kilometre residential limit, in an attempt to keep land in the possession of genuine farmers. Initially, this rule was discontinued for drought-affected areas (Joshi, 1988); it was universalised in 1995.

From the 1990s, the 'simplification of land policies' (Suresh Mehta, Minister for Industries, Government of Gujarat, 2002) has been a prominent governmental endeavour. In 1995, the BJP government amended Section 65 of the Bombay Land Revenue Act. This removed restrictions on the conversion of agricultural land to non-agricultural (NA) status for industrial development, up to 10 hectares (Indian Express, 1996). Going further on the land deregulation path, the government announced a New Land Policy in 1996. The main provision of the policy was that henceforth, persons holding navi sharat (new tenure) land for over fifteen years would be able to sell it for agricultural purposes, after getting it converted into juni sharat (old tenure) land. Until the promulgation of the New Land Policy, all newly allotted land in Gujarat came under the category 'new tenure'. This covered beneficiaries of land reforms in the 1960s and 70s, as well as beneficiaries of government schemes such as those for wasteland development. By 2003, the new-to-old-tenure provision was further liberalized, with all 'new tenure' lands automatically becoming 'old tenure'. No permission was required to make the change and to sell the land on. Moreover, the previous 
announcement allowing the conversion of agricultural land for non-agricultural purposes meant that new tenure land was now also open for sale for purposes beyond cultivation ${ }^{5}$.

In 1999, a circular from the Revenue Department announced the decision to sell gauchar or village common property pastoral land to industrialists. The latter would be charged 30 per cent more than the market value (Indian Express, 1999). Following protest by the Maldhari pastoralist community, the government withdrew the circular. However, as before, the local administration continued changing land use of village pastures on a case-bycase basis ${ }^{6}$.

In 2005, arrangements to privatize gauchars were mooted again. The BJP government introduced a Government Resolution (GR, JMN/3903/453/A) allowing privatisation of not just village pastoral land, but all wasteland (Government of Gujarat, 2005b). The GR indicates the government's intention to allot plots from among 46 lakh (4.6 million) hectares of state controlled wasteland to the corporate sector for establishing industries and to large farmers for technology-intensive and corporate farming. 19.84 lakh hectares of this 'wasteland' is deemed fit for cultivation. Each private actor is to be allotted up to 2,000 acres of land for a maximum of 20 years. There is no rent for the first five years and a minimal staggered rent of Rupees 40 to 100 per acre for the remaining time.

The state is willing to go to considerable lengths to aid its agents of growth. In its Industrial Policy of 2003, the government asserted its keenness to invoke the emergency clause in the Land Acquisition $\mathrm{Act}^{7}$ to acquire land speedily for industry (Government of Gujarat, 2003). Gujarat's land initiatives speak, not just to national economic change, but also to a dominant international policy discourse. International financial institutions have advocated an overhaul of the global land economy. Better and more accessible documentation through computerisation, the involvement of private actors in the generation of land records, and the deepening of the market in land are on their agenda (Deininger, 2008). In addition to deepening the market in land, Gujarat's government has attempted technological upgradation. In 2004-05, the e-Dhara project sought to computerize all village land records. User fees would be charged for access. The Bombay Land Revenue (Gujarat Amendment) Bill, 2010, underlined the need for computerisation of land records as a step towards transparency (Desh Gujarat, 2010).

\footnotetext{
${ }^{5}$ Retired Additional Chief Secretary, Revenue Department, interviewed in Ahmedabad, 15/10/04

${ }^{6}$ Serving District Collector, interviewed in Ahmedabad, 22/6/04

${ }^{7}$ The Land Acquisition Act of 1894 empowers the government to acquire private land for a public purpose under the eminent domain injunction. An Amendment in 1962 allowed land acquisition for a company engaged in a public purpose, including employment generation.
} 
The state has clearly been proactive in the deregulation of Gujarat's land market. This is in contrast with, say, West Bengal. The author's primary research in that region reveals that in the mid-1990s, the then Communist government of West Bengal contemplated land deregulation, to be competitive with regions like Punjab, Maharashtra and Gujarat. It was felt that the latter had attracted private investment 'worth crores' by offering tax incentives, but even more so, by making land available to investors ${ }^{8}$. The Cabinet prepared a proposal to make flexible the provisions of Section 14Y of the West Bengal Land Reforms Act of 1955, which imposes a ceiling of 7 hectares on land ownership, and is applicable to private companies, factories and infrastructure providers. However, the proposal did not see the light of day; it was rejected by the party's Politburo ${ }^{9}$. This inability to make an all-encompassing policy change compelled the West Bengal government to resort to individualized land provision to companies in later years, through the Land Acquisition Act. The political repercussions of this move are well known (Nielsen, 2009; Chakrabarty, 2011).

It is clear that Gujarat has been able to bring about systematic policy change in land, whereas other regions have not been as successful. Even Tamil Nadu, perceived as a frontrunner in economic growth post-liberalization, has provided land to private actors via land banks. The State Industries Promotion Corporation of Tamil Nadu (SIPCOT) acquires these. Like Gujarat, Tamil Nadu has changed land policy post-liberalization. But this is in the form of The Tamil Nadu Acquisition of Land for Industrial Purpose Act, $1999^{10}$. The latter makes acquisition of land easier for the state, rather than facilitating market exchange, as has been attempted in Gujarat.

Our analysis should not stop at highlighting Gujarat's strides in land liberalization. After all, the making of policy is an effect of a conducive economic environment. We must now ask: what has made these policy effects possible? The sub-text of this question would be: why are these effects not visible in other Indian regions? In response, I analyse Gujarat's proactive land policy from the 1990s through insights from (a) its history of intervention in the land economy; (b) the nature of government institutions that engage with land; (c) the politics and political economy, including political leadership, that has buoyed changing land policy.

\footnotetext{
${ }^{8}$ Interview with retired West Bengal Administrative Service official, who has worked for much of his career in the Land Reforms Tribunal and Land Reforms Department, Kolkata, 26/12/2011

${ }^{9}$ Ibid.

${ }^{10}$ IAS Officer, Secretary to the Government of Tamil Nadu, interviewed in Chennai, 16/8/2012
} 


\section{History, institutions and politics in Gujarat's proactive land policies}

The proactiveness of the Gujarat state in land is not new. The dynamism we see in the post-reform era is also visible pre-reform. A slew of land reform legislation was devised from the early 1950 s to the early 1970s, aimed at greater productivity, efficiency and social justice, in that order. Land was to be taken from former princely estates, and intermediaries in land, and redistributed first amongst the tenant tillers, and then amongst landless labourers who performed much of the work and had few rights. Like land reform across the country, Gujarat's land legislation faced resistance. In the case of the Saurashtra Land Reforms Act 1951 and the Saurashtra Estate Acquisition Act $1952^{11}$ for instance, due to drought in 195051 , only 86 of the 55,000 tenants on lands formerly owned by intermediaries could pay six times the revenue assessment, which was the agreed sum for purchasing occupancy rights. To solve the problem, Chief Minister U.N. Dhebar held negotiations with his officials, the Bank of Saurashtra and the Reserve Bank of India to devise a loan scheme which would allow farmers to purchase land. A Land Mortgage Bank was also formed. This was a cooperative venture of farmers, with 20,000 members. The legal titles of the lands of tenant-occupants were mortgaged with the Bank until they had paid the full amount required for ownership ${ }^{12}$. Between 1948 and 1951-52, 55,000 former tenants obtained occupancy rights over 12,00,000 acres of land. 33,000 former intermediaries were allotted land for self-cultivation.

The context for land reform in mainland Gujarat was different from Saurashtra. Under colonialism most of its land had been administered under the raiyatwari system. That is, revenue was collected by the state directly from the cultivating peasant. However, cultivators who controlled large tracts of land did sub-contract it to tenants, and therefore came under the tenancy reform legislation of the Bombay Tenancy and Agricultural Lands Act 1948. The Act aimed at securing the tenure of tillers who had hitherto been ejected at will, and at assuring reasonable rents. Over time, excess land was to be passed on to the ownership of the tenant cultivators.

State proactiveness in land reform in Gujarat was mitigated by political context. Only some phases of land reform achieved a modicum of success in select parts of the region. The partial nature of the phenomenon is down to politics. The majority of intermediaries in Saurashtra were British-loyalist upper caste Rajputs with no links with the Congress party, and only nascent independent political organisation. Thus, the Congress had little stake in

\footnotetext{
${ }^{11}$ Gujarat as we know it today was formed from three separate regions: Saurashtra, Kachchh, and a sub-set of Bombay Province, in 1960.

${ }^{12}$ Retired IAS officers, interviewed in Ahmedabad, 13/8/04 and 14/10/04
} 
obstructing the government in its task of reform. The chief beneficiaries of intermediary abolition on the other hand were former tenants, mainly Kanbi-Patidars. The latter had based their quest for socio-political mobility on their participation in the freedom movement and support to the Congress party (Hardiman, 1981). Land ownership owing to the reforms also set this important group on the path to economic mobility.

On the other hand, upper- and middle-caste farmers, especially Patidars controlled substantial tracts of land in central, mainland Gujarat. The politicians and bureaucrats who had zealously uprooted Rajput zamindars and granted ownership rights to former tenants in Saurashtra, failed to do so as successfully in mainland Gujarat. Only half the area held under tenancy was declared by landowners. Even within this group, about 40 per cent of the tenants were then denied their tenancy rights and made to surrender their land to the landlords. Few tenants could protest because they were kept away from the hearings of the tribunals that were set up to arbitrate disputes (Desai 1971, in Shah and Sah, 2002). In short, it would be hard to term Gujarat's state universally dynamic and pro-land reform. It may have had a series of sophisticated land reform measures, but these by themselves tell us little. The effects of land reform policy on the ground were varied, and these effects were mediated by political conditions.

Having looked at the role of history in Gujarat's land economy, I turn now to government institutions and their intervention in contemporary land liberalization. Sinha (2005) has commented on the role of key government institutions such as the Industrial Extension Bureau (iNDEXTb), and a largely pro-reform bureaucracy, in the readying of the state for embracing liberalization. In the field of land, my interviews with bureaucrats from relevant departments such as Land Revenue and Industry, underline this point. My aim here though is to not just comment on the official role of state institutions, but on their usually overlooked personalised, business-friendly and extra-legal role in facilitating land transfers to private players.

As we have seen above, state institutions have produced timely and extensive policy in land. This policy has had to be followed up in various ways in order to take effect. To recall the multi-layered state as idea, institutions and politics outlined a few pages ago, first, this state has been critical for generating a legitimating rhetoric for land liberalization. For instance, when the 8-kilometre rule was lifted in 1987, the Revenue Minister, from the Congress Party, asserted it represented improvements in land laws, as it would facilitate mobility and entrepreneurship (cited in Vyas et al, 1989). Similarly, when A to NA conversion was mooted on an automatic basis, the Industries Minister, Suresh Mehta of the 
BJP, called the move 'revolutionary'. He indicated that this would lift hurdles in acquiring land for industrial purposes, thus ensuring faster development (Indian Express, 1996).

That the state's legitimating rhetoric is powerful, and has enduring effects, is evident in the couching of common property land, including pastoral gauchars, within the broad category of 'wasteland' in the 2005 Government Resolution that seeks to privatize the latter (see above). Crucially, while this GR places faith in the entrepreneurial abilities of 'big industrial houses' and 'individual competent farmers' (Government of Gujarat, 2005: 1), providing attractive terms to encourage them, land to the poor schemes are given a vote of no confidence. The GR articulates the prevalent belief in the government that the aim of bringing a large area of Government wasteland under plough has not been achieved' (ibid.: 1). It is expected that the new entrepreneurs on this land will take along those left behind by 'providing employment opportunities to agricultural labourers and skilled workers' (ibid.: 1). Here, one sees the state ally with what it sees as productive and 'competent' development actors, and endorses their path of productivity in the form of industrialisation and corporate farming. Small scale farming and redistributive development is rejected as invalid. The taking of sides by the state, first discursively, and then by the follow through of policy practice, is both powerful and telling.

Apart from generating an institutional validating discourse, Gujarat's state has offered personalized services to those interested in the land market. For instance, as we have seen already, the state has declared its readiness to operationalize the emergency clause in the land acquisition act, seeking land for private actors on the pretext of it being for a public purpose. Further, as a Secretary to the Government confirmed to this author, land-related departments have instructions to do all they can to ensure that investors, Indian and international, access land of their choosing without bureaucratic delay ${ }^{13}$. This zeal was clearly visible in the Tata Nano case of 2008 where a major car manufacturing plant was uprooted from West Bengal on account of political opposition to land acquisition. With multiple regional governments including Punjab, Haryana, Uttarakhand, Rajasthan, Andhra Pradesh Maharashtra and Karnataka vying for the Nano factory, Gujarat won the day by offering Tata 1000 acres. As the Chairperson of the company indicated in an interview,

\footnotetext{
. . . The Gujarat chief minister moved really fast . . In other states there were processes to be gone through or things which the legislative assembly had to do which may or may not happen despite the best intention of the chief minister of the state . . Gujarat was able to define the land, secure possession of the land, the main thing, at an unbelievably fast pace. In fact, if we could move a plant in a day, we could have actually started operating here, given the fact that everything
}

\footnotetext{
${ }^{13}$ IAS officer, interviewed in Gandhinagar, 26/9/04.
} 
was ready in the state... Whatever we were offered in Singur, everything is being matched here.

The elements [incentives] may not be identical, but in totality, the package is the same.

Ratan Tata, in The Economic Times, 7 October $2008^{14}$

As the Government of Gujarat moved by executive order rather than the legislative route, its deal with the Tatas remains largely secret. Early reports in the press suggested that the market price of the land given to the Tatas in Sanand (hitherto controlled by the Anand Agricultural University) is Rs 2,500 per square metre. However, the company was asked to pay Rs 1,000 per square metre. It is also believed that the government undertook to handle any financial or legal liabilities that may be associated with the land or the wider project, including environmental conditionalities such as the treatment of water and effluents. Massive tax incentives too are on offer. We will have to treat this information as conjecture as even the main opposition party's demands for information have been rebuffed (Sud, 2008).

On a smaller scale than the Tata case, but showing the same kind of personalisation of state-business relations in land, is evidence from a Secretary to the Government of Gujarat. He informed this author that senior Revenue and Industry department bureaucrats in the regional capital regularly recommend that interested investors employ retired government officials such as land revenue officers to get around the intricacies of land acquisition ${ }^{15}$. In the fast-track liberalization of land, while the conversion of large tracts of agricultural land to non-agricultural purposes, or for circumvention of land ceiling laws is facilitated by the government apparatus in the regional capital, the groundwork is done by former government employees, or current employees on deployment, well versed in how the state works.

The examples of ideational and institutional interventions in the land market that I have given so far are within the realm of legality, even as they show a business-friendly personalisation of government. As a final point, I will dwell on official institutional interventions in the land market that are extra-legal. The information I provide is based on interviews with senior government officials, including a former Secretary to the Government of Gujarat who now advises large business conglomerates post-retirement.

In 1999, a Gujarati NRI, Dilip Barot and his Ahmedabad-based brother were handed the ambitious Infocity project for building an Information Technology Park on 150 acres of prime land near Gandhinagar, the capital city. Being builders, they had no previous experience in IT. Bids were sought for the project, though developers had only 15 days to prepare these. Three companies, Creative Choice of the Barot brothers Larsen and Toubro

\footnotetext{
14 'We are not orphans out to get a home: Ratan Tata', The Economic Times, Mumbai Edition, 7/10/08.

${ }^{15}$ IAS officer, interviewed in Gandhinagar, 26/9/04.
} 
and a Malaysian firm were the only bidders, though the latter two withdrew at the last minute. Newspapers reported that they had been persuaded to do so by interests in the government that were close to the Barots (Desai and Ray, 2001). A senior government official recalled a similar experience from 2001. His suggestion that competitive bids be invited for a large infrastructure project in Kachchh was brushed aside and the contract awarded to a predecided party ${ }^{16}$. The incidents reported here are from the late 1990s and early 2000s. Only in 2006, as a post-facto measure, an amendment was made to the Gujarat Infrastructure Development Act 1999, allowing 'direct negotiation'. Now under Section 10A, innovative projects such as those involving proprietary or patented technology, or providing infrastructure essential to a larger project, can be passed without tendering (Government of Gujarat, 2006).

An even more blatant example of the extra-legality that underlies Gujarat's thriving land market comes from the involvement of various levels of the state, politicians and what has been called the 'shadow state' (Harriss-White, 2003) comprising middlemen and fixers, in (a) the acquisition of agricultural land for non-agricultural purposes in the new economy, and (b) the rapid conversion of this land to NA status. While laws are in place to enable both of these processes, officials readily admit to an imperfect market that is slow, cumbersome to manoeuvre and full of information asymmetries. In this context, private players such as business houses that want to purchase large quantities of land, hire the services of current or former government officials (as stated above). It is the job of the latter to then bring on board local politicians and musclemen. Members of the shadow state, who may well have close, including familial, links with local government and politics, work closely with the formal state to speed up land sales, including coercing recalcitrant sellers. Once the required amount of land has been bought, extra legal mechanisms are in place to convert this to NA. The nexus of land conversion goes to the top of the bureaucratic and political pyramids, with different layers of the state taking a fixed cut, for each square foot of land, that is made $\mathrm{NA}^{17}$.

In short, land has been deregulated in Gujarat in order to facilitate an open market. However, in the face of continued imperfections and power imbalances, the state quite openly takes sides in the land market and in the process continues to be a key player in the economy of a liberalized resource. In the terminology deployed by this paper, institutions of the state, ranging from government departments to local councils, are involved in deft manoeuvring between market- and business-friendly practices, both legal and extra-legal. It can be argued

\footnotetext{
${ }^{16}$ IAS officer, interviewed in Gandhinagar, 15/7/04.

${ }^{17}$ Retired IAS officer, interviewed in Ahmedabad, 23/12/08
} 
that the role performed by state norms and state institutions in the market for land can easily be replicated in other regions. After all, legitimating neo-liberal rhetoric, or extra-legal practices in favour of chosen private players, cannot be limited to Gujarat's state. Both are prevalent in, say, West Bengal and Tamil Nadu, as shown by the author's on-going research there. In the last sub-section, I will suggest that Gujarat's market in land has been effectively liberalized, not just because of an 'efficient' state, but also because of the politics within which this state functions. The latter conditions are difficult to replicate across the country.

Politics in Gujarat is represented by a relative lack of opposition to liberalization, and by a sameness of positions across party political lines. It is not that liberalization of land, which has affected users of common property resources and small farmers adversely, has faced no dissent. We have seen above that the proposal to make pastoral land available for industrial purposes from 1999, was opposed by herders. However, this protest only led to a temporary abeyance. From 2005, not just pastoral land, but many other types of common property land can be privatized on lease for industrial purposes. Whatever protest has emerged has been tackled by the state or private players, with one popular tactic being to buy off potentially disruptive NGOs, activists or local community groups, when a project is first mooted $^{18}$.

When local groups have opposed land liberalization, as was the case of the NGO Lok Adhikar Sangh that questioned the privatisation of a forest for mining for a cement factory in Kachchh in 1995, this opposition was neutralized by other local constituencies, i.e. of traders, vehemently supporting land liberalization for the sake of business development (see Sud, 2009). Finally, on occasion, one has heard of protest from within party political factions. For example, in 2009-10, the Member of Legislative Assembly of Mahuva in Saurashtra, a ruling party leader called Kanubhai Kalsaria, strongly opposed the acquisition of land for a Cement Plant to be built by Nirma Industries Limited in Mahuva. Kalsaria had concerns about the loss of livelihood of his primarily agrarian constituents. He also questioned the environmental impact of cement manufacturing in the area. At the same time, he did not seem to be averse to the Nirma cement operation being set up elsewhere (Varma, 2011).

Despite occasional protest, Gujarat lacks a broader movement against land liberalization. Moreover, powerful groups in the polity and economy have been supportive of the opening up of the land market. We have encountered the Kanbi-Patidars as both beneficiaries and evaders of post-independence land reform, in different parts of the region. It

\footnotetext{
${ }^{18}$ Ibid.
} 
was suggested that land reform set this group on the path of political mobility. As the Patidars have diversified economic activity, younger generations have shifted to urban or peri-urban areas to set up agro-business and other kinds of enterprise (Rutten, 1995). It has been in the Patidars' interest to seek the liberalization of land; to easily convert their agricultural land to industrial purposes, and to be able to buy and sell land without residential restrictions. Farmers associations, such as the Bharatiya Kisan Sangh, which are headed by Patidar landowners, have thus been at the helm of negotiations with the government regarding the opening up of the land market. It is they that pressurized the Congress regime of 1987, for instance, to do away with the 8-kilometre residency rule ${ }^{19}$. In short, liberalization, including land liberalization, may be part of international capitalist trends, but it has found a conducive setting in Gujarat where there is also a favourable local constituency.

Beyond immediate stakeholders in the land liberalization process, the wider political space has been marked by a silence about the fundamental changes in the land market (and indeed other liberalizing markets). One reason for this is the dominance of Hindu nationalist politics in the region, with issues of identity, and Hindu-Gujarati pride dominating political debate from the mid-1980s. Economic factors have been discussed in this scenario, but amongst narrow constituencies of entrepreneurs, farmers, government officials, etc. The wider political space has not seen nuanced economic debate. Even when economic issues are on the popular agenda, say when the high profile Nano car factory shifted from West Bengal to Gujarat, the particularities of the Tata Nano deal with the state were not in the limelight. Instead, public discussion in, for instance, blogs and other media, or in letters to newspapers, was about the pride Gujaratis must feel in bagging the Nano project in the face of stiff competition from other regions. The state played up this rhetorical, chauvinistic trend, demonstrated in the following press note:

\section{All sections of the society of Gujarat welcome the Nano car project in the State. \\ All treat this as a prestigious symbol of Gujarat's robust march towards becoming a Global Industrial Hub and Investment Destination.

Having looked at the politics of opposition to, and support for, Gujarat's changing land laws, I now move on to contextualising this in Gujarat's larger party political system. The invalidating of political protest against land liberalization in individual cases is made possible by the hollowness of Gujarat's party system. There are only two main political parties, one of which, the Congress, has been in longstanding decline and has not won a

\footnotetext{
${ }^{19}$ Leader, Vadodara Jilla Khedut Samaj, interviewed in Baroda, 21/8/04; Leader, Bharatiya Kisan Sangh, interviewed in Gandhinagar, 20/9/04
} 
simple majority since 1985. Second, unlike other parts of India, which have seen a broadening of democracy, and the coming on board of more and more political actors in the 1980s and 90s, Gujarat has seen a narrowing in its politics. One party, the BJP, has been in power since 1990 almost continuously. Even within the party, dissent has been sidelined and one individual has reined as Chief Minister since 2001. This is not even a career politician, but someone who rose through the ranks of the authoritarian Hindu nationalist movement, which is coordinated by the RSS. The incumbent CM fought his first popular election after being made Chief Minister. He has been called 'autocratic' by his own colleagues, as he broaches no dissent ${ }^{20}$. The centralisation of decision-making that is his hallmark facilitates the business-friendly liberalization process. The Chief Minister's Office (CMO), an increasingly powerful institution, has worked closely with business to market 'Brand Gujarat'. I have interviewed CEOs who vouch for the CMO's efficiency. The CMO and its boss will apparently remove all hurdles in attaining land, even if that means skirting around official procedure $^{21}$. The narrowing of Gujarat's democracy is underlined by the longstanding absence of anti-caste or radical labour politics in the region. Lower caste parties, which could lend an alternative voice in politics, have never emerged in Gujarat. This is not the case for many other Indian regions.

The sort of restrictive politics discussed in this section has been impacted by a constricted legislative process. An increasingly centralized state, where key decisions tend to be made by the CMO, has less and less regard for the legislature. For instance, in August 2004, the Chief Minister called a day's special session of the Legislative Assembly to condole the death of a political leader. He then decreed that the requirement for the Assembly meeting once in six months had been fulfilled and the House need not meet till February 2005. Again, in 2006, a two-day session was held in September, though the opposition demanded at least fifteen days. The opposition and his own party men feel that this is a deliberate attempt to avoid discussing important issues at the legislative level ${ }^{22}$. In earlier decades, legislators would meet in the State Assembly for around 60 days in a year. From the 1990s, this number fell to around 35 and has been further reduced in the present decade. In this context of legislative weakness, important economic decisions with relation to land have been taken via executive order, instead of being debated in the Assembly. This skirting

\footnotetext{
${ }^{20}$ Interview with BJP leader from South Gujarat, Surat, 16/7/04

${ }^{21}$ CEO of South Gujarat company, interviewed in Surat, 14/7/04

${ }^{22}$ Interview with BJP leader from South Gujarat, Surat, 16/7/04
} 
around the political process may facilitate fast-track liberalization, but like many other aspects of Gujarat's politics, it is inimical to democracy.

This section has highlighted the politics that underlies Gujarat's success in opening up its land market. I have discussed lack of popular participation in economic decisionmaking, the weakness of the party political system, centralisation of executive decisionmaking, the homogenisation of politico-economic stances, and a limited legislative process. The political conditions of Gujarat's land market 'efficiency' have, unsurprisingly, not been replicated in many other parts of India, which are politically more vibrant.

\section{Conclusion}

This paper has analysed the playing out of economic reform in one regional state. Corroborating existing literature, it has appealed for regional focus and nuance, taking into account factors of history, policy and politics. Agreeing with the heterodox literature on the state under market reform, it has posited an entity that is at the centre of the new political economy, rather than on the regulatory sidelines. The state has been conceptualized as a bundle of ideas, bureaucratic institutions and policies, and as embedded in varied levels of politics.

As discussed in the review of literature, the state has been critical in the regional political economy of reform across India. Yet, the capacity of this entity has varied greatly. This has been the case in history, given vast regional developmental divergence in the postindependence period. This is even more apparent today, when states can compete directly with each other and other international sub-national regions to attract investment and forge neo-liberal development. Some regional states possess the ability to refract and build on liberal policy impulses emerging from Delhi, while other states continue to depend on the centre for policy direction, coordination, training and funding. The vast variations in infrastructure policy indicated in the preceding pages, the strides made by some regions, and the dependence of others on the central government and international organisations, highlights this point.

The general findings of this paper are deepened by the detailed case study of Gujarat. Gujarat's state has emerged as particularly successful in the competition for privatized economic development. In foundational areas such as infrastructure reform and land deregulation to service the new economy, it is well ahead of its competitors, having initiated timely and extensive liberalization. Across political regimes, the state has encouraged broadly market-friendly reform, onto which business-friendly conditions for its chosen private 
partners have been incorporated. State officials and politicians have readily occupied the interstitial spaces of extra-legality in order to attract business-friendly growth. In doing so, they follow the path of a state that has been historically proactive and entrepreneurial, and one which is not constrained by the demands of competitive, democratic politics.

Gujarat's very specific political conditions, in fact, set it apart from other regions. With muted and scattered resistance to liberalization; a consensus about neo-liberal policies across the two main parties; a weak political opposition; a substantive lack of anti-caste, left or labour politics; a chauvinistic Hindu nationalism around which much of the polity has cohered; and an authoritarian leader who has branded himself as the champion of Hindus as well as neo-liberal reform, it is easy to see why the conditions one sees in Gujarat are difficult to replicate. While much of the rest of India has witnessed a broadening of democracy, Gujarat is a case of a decided narrowing. It is this context that provides the perfect conditions for efficient economic reform. That these conditions are not easily replicable across India is a good thing.

\section{$\underline{\text { References }}$}

Abrams, P. (1988) 'Notes on the Difficulty of Studying the State', Journal of Historical Sociology, 1(1), pp. 58-89

Asian Development Bank (2008) IND: Gujarat Power Sector Development Program, Project No. 29694, Completion report. Manila: ADB

Bhatt, N. B. (2005) 'GERC to hear GEB's claim for Rs 1,255 cr dues from Essar', The Times of India, Ahmedabad Edition, 23 September

Brenner, N. (1999) 'Globalisation as Reterritorialisation: The Re-scaling of Urban Governance in the European Union', Urban Studies, 36(3), pp. 431-51

Brenner, N. (2004) New State Spaces: Urban Governance and the Rescaling of Statehood, New York: Oxford University Press

Chakrabarty, B. (2011) 'The Left Front's 2009 Lok Sabha Poll Debacle in West Bengal, India: Prospective Causes and Future Implications', Asian Survey, 51(2), pp. 290-310. 
Chang, H-J. (2004) Globalisation, Economic Development and the Role of the State, London: Zed Books

Collier, P. (2007) The Bottom Billion: Why the Poorest Countries are Failing and What Can Be Done About It. Oxford: OUP

Corbridge, S., S. Jewitt and S. Kumar (Eds.) (2004) Jharkhand: Environment, Development, Ethnicity, Delhi: Oxford University Press

Corbridge, S. (2011) 'The contested geographies of federalism in post-reform India', in S. Ruparelia, S. Reddy, J. Harriss and S. Corbridge (Eds.) Understanding India's New Political Economy. A Great Transformation? New York: Routledge, pp. 66-80

Deininger, C. (2008) 'A Strategy for Improving Land Administration in India', Agricultural and Rural Development Notes, Issue 33, Washington: The World Bank

Desai, D. and J. Ray (2001) 'IT king's jacuzzi sank a high-rise', Indian Express, Ahmedabad Edition, 5 March

Desh Gujarat (2010) 'Gujarat to computerise land records, bill passed in assembly', Desh Gujarat, March 2, http://deshgujarat.com/2010/03/03/gujarat-to-computerise-landrecords-bill-passed-in-assembly/

Doornbos, M. (2006) Global Forces and State Restructuring. Dynamics of State Formation and Collapse. London: Palgrave Macmillan

Evans, P. (1995) Embedded Autonomy. States and Industrial Transformation, Princeton, NJ: Princeton University Press

Frankel, F.R. (2005) India's Political Economy 1947-2004. The Gradual Revolution, Second Edition, Oxford: Oxford University Press

Godbole, M. (1996) Unfinished Innings. Recollections and Reflections of a Civil Servant, New Delhi: Orient Longman

Gore, C. (2000) 'The Rise and Fall of the Washington Consensus as a Paradigm for Developing Countries', World Development, 28(5), pp. 789-804

Government of Gujarat (n.d.) 'e-Dhara: Land records online', Gujarat Informatics Limited, http://www.gujaratinformatics.com/edhara.html

Government of Gujarat (1998) 'Policy for Supply of Surplus Electrical Power to Group companies \& GEB/Licencees [sic], wheeling of Power, etc. by Captive Power Projects', Resolution No. CPP 1179/2253/PP Cell, 9 November, Gandhinagar: Government of Gujarat

Government of Gujarat (2003) Gujarat Going Global. Gujarat Industrial Policy 2003, Gandhinagar: Industries and Mines Department, Government of Gujarat 
Government of Gujarat (2005a) Blueprint for Infrastructure in Gujarat (BIG 2020): Summary Report, Gandhinagar: Government of Gujarat

Government of Gujarat (2005b) 'Resolution No. JMN/3903/453/A (Part-I)', Gandhinagar: Revenue Department, Unpublished government order, 17 May

Government of Gujarat (2006) 'The Gujarat Infrastructure Development (Amendment) Act, 2006', Published in Gujarat Government Gazette, Part 4, 31 March. Gandhinagar: Goernment of Gujarat. http://www.gidb.org/cms.aspx?content_id=94

Government of Gujarat (2008) 'Ratan Tata announces the investment of his dream Nano car project in Gujarat', Press Note, Gandhinagar: Gujarat Information Bureau

Government of India (n.d.) Promoting Infrastructure Development Through PPPS: A Compendium of State Initiatives, New Delhi: Department of Economic Affairs, Ministry of Finance, Government of India

Government of India (2010) Compendium of PPP Projects in Infrastructure, New Delhi:

Secretariat for Infrastructure, Planning Commission

Government of India (2011) 'The Land Acquisition, Rehabilitation and Resettlement Bill, $2011^{\prime}$

Government of India (2012) Source: Secretariat of Industrial Assistance, Department of Industrial Policy and Promotion, GoI, http://dipp.nic.in/English/Publications/SIA Statistics/2012/feb2012/stat26.htm

Hardgrave, R.L. (1983) 'The Northeast, the Punjab, and the Regionalization of Indian Politics', Asian Survey, 23(11), pp. 1171-81

Hardiman, David (1981) Peasant Nationalists of Gujarat. Kheda District 1917-1934. Delhi: Oxford University Press

Harriss-White, B. (2003) India Working, Cambridge: Cambridge University Press

Indian Express (1996) 'Land Acts to be amended to favour industry', Indian Express, Ahmedabad Edition, January 4

Indian Express (1999) 'Maldharies against circular', Indian Express, Ahmedabad Edition, 22 February

Jenkins, R. (1999) Democratic Politics and Economic Reform in India, Cambridge: Cambridge University Press

Jessop, B. (1999) 'Narrating the Future of the National Economy and the National State? Remarks on Remapping Regulation and Reinventing Governance', in G. Steinmetz (Ed.) State/Culture, Ithaca: Cornell University Press, pp. 378-406 
Joshi, C.M. (1988) 'Tinkering With Gujarat Land Laws', The Times of India, Ahmedabad Edition, 10.9.88

Kennedy (2009) 'Large-scale economic and infrastructure projects in India's metropolitan cities: New policies and practices among competing subnational states', Paper presented at the $4^{\text {th }}$ International Conference of the International Forum on Urbanism, Amsterdam, Delft

Kohli, A. (2006) 'Politics of Economic Growth in India, 1980-2005', 2 Parts, Economic and Political Weekly, 41(13, 14), pp. 1251-59 and 1361-70

Kohli, A. (2012) Poverty Amid Plenty in the New India, New York: Cambridge University Press

Kothari, R. (1964) 'The Congress “System” in India', Asian Survey, 4(12), pp. 1161-73.

Kulke, H. and B. Schnepel (Eds.) (2001) Jagannath Revisited: Studying Society, Religion and the State in Orissa, New Delhi: Manohar

Mehta, Suresh (2002) Speech of Suresh Chandra Mehta, Minister of Industry and Tourism, Government of Gujarat at the Interactive Meet on Resurgent Gujarat, Federation of Indian Chambers of Commerce and Industry, New Delhi, January 82002.

http://www.ficci.com/ficci/media-room/speeches-presentations/2002/Jan/jan-gujratmehta.htm, accessed 17/10/05.

Neilsen, K.B. (2009) 'Four Narratives of a Social Movement in West Bengal', South Asia, 32(3), pp. 448-68.

Nettl, J.P. (1968) 'The State as a Conceptual Variable', World Politics, 20(4), pp. 559-92

Pai, S. (Ed.) (2007) Political Process in Uttar Pradesh: Identity, Economic Reforms and Governance, New Delhi: Pearson Longman

Raghu, S. (2007) 'Gujarat abolishes octroi in seven crucial cities', Live Mint, 14 November, http://www.livemint.com/Politics/ozJcnYcohaaQe6ViSH8qzM/Gujarat-abolishesoctroi-in-seven-crucial-cities.html

Rutten, M.F. (1995) Farms and Factories: Social profile of large farmers and rural industrialists in West India, Delhi: Oxford University Press

Sanghavi, N. and U. Thakkar (2000) 'Regionalisation of Indian politics', Economic and Political Weekly, 35(7), pp. 514-518

Schomer, K., J.L. Erdman and D.O. Lodrick (1994) The Idea of Rajasthan: Explorations in Regional Identity, New Delhi: Manohar Publishers and Distributors 
Shah, G. and D.C. Sah (Eds.) (2002) Land Reforms in India. Performances and Challenges in Gujarat and Maharashtra, Volume 8, New Delhi: Sage Publications

Sinha, A. (2004) 'The Changing Political Economy of Federalism in India: A Historical Institutionalist Approach', India Review, 3(1), pp. 25-63.

Sinha, A. (2005) The Regional Roots of Developmental Politics in India. Bloomington, IN: Indiana University Press.

Sud, N. (2008) 'The Nano and Good Governance in Gujarat', Economic and Political Weekly, 43(50), pp. 13-14

Sud, N. (2009) 'The Indian State in a Liberalizing Landscape', Development and Change, 40, (4), pp. 645-65

Sud, N. (2012) Liberalization, Hindu Nationalism and The State: A Biography of Gujarat, New Delhi: Oxford University Press

Tilly, C. (Ed.) (1975) The Formation of National States in Western Europe, Princeton: Princeton University Press

Times News Network (2011) 'Raj to have infrastructure act soon', The Times of India, Jaipur, January 10, http://articles.timesofindia.indiatimes.com/2011-0110/jaipur/28378192_1_land-bank-ashok-gehlot-desert-state

Toye, J.F.J. (1987) Dilemmas of Development: Reflections on the Counter-Revolution in Development Theory and Policy, Oxford: Basil Blackwell

Trivedi, S. (2007) 'Congress campaign to focus on development, Modi's 'crorepatis', Business Standard, November 27, http://www.businessstandard.com/article/economy-policy/congress-campaign-to-focus-on-developmentmodi-s-crorepatis-107112701084_1.html

Vadlamannati, K.C. and H. A. Khan (2012) 'Race to the Top or Race to the Bottom? Competing for Special Economic Zones (SEZs): Evidence from Indian States, 19982010', Working Paper, Alfred-Weber Institute for Economics, University of Heidelberg.

http://www.uniheidelberg.de/fakultaeten/wiso/awi/professuren/intwipol/vadlamannati en.html

Varma, G. (2011) 'Q\&A, Kanu Kalsaria, BJP MLA, Mahuva Gujarat', Business Standard, March 29, http://www.business-standard.com/article/economy-policy/q-a-kanukalsaria-bjp-mla-mahuva-gujarat-111032900054_1.html 
Vijayabaskar, M. (2010) 'Saving Agricultural Labour from Agriculture: SEZs and Politics of Silence in Tamil Nadu', Economic and Political Weekly, February 6, Vol. XLV, pp. $36-43$

Vyas, B., Parmar, R., Parmar, K., Chaudhary, A., Jani, M., Khatsuriya, H., Mahida, C. and Yagnik, A. (1989) 'Gujarat Sarkarni Garib-Virodhi Chaal Jamin Kaydama 'Chutchat' ni Jaherat', Pamphlet, Ahmedabad:Gujarat VishamtaNirmulan Parishad (in Gujarati)

Weiner, M. (1998) 'The regionalization of Indian politics and its implications for economic reform', The Journal of Policy Reform, 2(4), pp. 337-67

World Bank (1994) World Development Report: Infrastructure for Development, New York: Oxford University Press

World Bank (1997) World Development Report: The State in a Changing World. New York: Oxford University Press

Yagnik, A. and S. Sheth (2005) The Shaping of Modern Gujarat: Plurality, Hindutva and Beyond. New Delhi: Penguin Books 